\title{
Legekunst på legevakt
}

\author{
Venterommet på legevakten er gjerne fullt av pasienter legen aldri har møtt før. Som legevaktlege skal du \\ finne de alvorlig syke blant de mange som det ikke feiler noe alvorlig. Du har lite tid til rådighet. I løpet av \\ konsultasjonen må du skaffe deg tilstrekkelig informasjon til å bestemme deg for videre tiltak, samtidig som \\ du skal skape tillit og trygghet hos pasienten. Konsekvensene av dine beslutninger kan være store. Hvordan få \\ til godt legevaktarbeid?
}

Legevaktarbeid er en egen medisinsk disiplin som utøves i grenselandet mellom allmennmedisin og akuttmedisin. Legevaktene driver med akutt allmennmedisin og er samtidig del av den akuttmedisinske førstelinjen. Erfaringene som ligger til grunn for denne teksten er fra Legevakten i Oslo, en stor bylegevakt med mange leger og sykepleiere til stede døgnet rundt, observasjonssenger, røntgenavdeling og døgnåpen akuttsosialtjeneste. Det er et stort spenn fra dette til den ensomme legen på vakt $i$ et stort og grisgrendt distrikt. Trass i forskjeller i størrelse og organisasjonsform legevaktene imellom har legevaktarbeidet i seg selv noen bestemte utfordringer (1).

Legevakt er legearbeid med uselekterte, ukjente og ofte mange pasienter. Som legevaktlege har du lite tid til disposisjon. Enten fordi akkurat denne pasienten kan være alvorlig syk og/eller fordi venterommet er fullt av andre som også kan være alvorlig syke. Legevaktens skrekk og gru er farlige tilstander som er vanskelige å diagnostisere tidlig i forløpet eller lette å overse om man ikke har dem spesielt i tankene - eller begge deler - som for eksempel meningitt, appendisitt og lungeembolisme.

Sortering er vårt verktøy i møte med en slik pasientmengde der noen få er svært alvorlig syke, men flertallet ikke. Ved ankomst må pasientene triageres og sorteres etter antatt hastegrad. Det finnes en rekke standardiserte systemer for triage, men viktigere enn hvilket man bruker, er at det blir gjort. Videre trengs systematisk tilsyn av dem som må vente, for å fange opp forverring i ventetiden. Når pasienten treffer legen, sorterer legen til egnet behandlingsnivå og bestemmer hastegraden av videre tiltak.

\section{Tiltak er viktigst}

Det sentrale ved legevaktvirket er å fatte beslutninger om tiltak. Tiltak er viktigere enn diagnose. Det betyr at hva du skal gjøre med pasienten er viktigere enn å finne ut eksakt hva vedkommende feiler. Det er tre grunnleggende spørsmål: Kan dette være farlig? Må behandling startes her og nå? Kan jeg sende pasienten hjem?
Om pasienten feiler noe som er farlig, er neste spørsmål hvem som skal gjøre noe med det. Er det sykehuset? Er det deg? Om pasientens tilstand verken er farlig eller behandlingskrevende her og nå, kan vedkommendes plager utredes videre av fastlegen. Her og $n a ̊$ omfatter det som må avklares de nærmeste to døgn. Ikke glem at ekspektans er et aktverdig tiltak som mange er blitt friske av. Om du ikke kan sende pasienten hjem, må du gjøre noe annet.

For pasienten finnes det kun tre veier ut av en konsultasjon ved legevakten: til sykehus, til observasjon lokalt eller hjem med en egnet plan. Jo mer sammensatt og innfløkt pasientens problem fremstår, desto større

\section{«Grunnlaget for lege- vaktlegens beslutning skal være så tynt som mulig, det vil si godt nok»}

nytte vil du ha av å ha klart for deg at konsultasjonen bare har disse tre utgangsdørene. Dette gjelder også ved psykiske lidelser, kroniske tilstander og sosiale problemer. Som tilfeldig forbipasserende legevaktlege er det en rekke problemer du bør avstå fra å prøve å løse, problemer som med fordel kan overlates til pasientens vanlige behandlere neste virkedag. De kjenner pasienten, det gjør ikke du. Ditt viktigste bidrag vil være å møte pasienten med interesse og omsorg.

\section{Beslutningsgrunnlag}

Legevaktleger må være gode klinikere. Våre viktigste verktøy er anamnese og enkel og målrettet klinisk undersøkelse. Grunnlaget for legevaktlegens beslutning skal være så tynt som mulig, det vil si godt nok. Mer har du ikke tid til. Du skal skaffe deg de anamnestiske opplysningene og gjøre de kliniske og supplerende undersøkelsene du trenger for å fatte beslutning om tiltak, men heller ikke mer. Mye kan gjøres enkelt, målrettet og raskt, men noe må gjøres mer omfattende og tar tid. Det er en viktig legevaktferdighet å kunne veksle mellom grundighetsnivå etter hva situasjonen krever.

De fleste problemstillinger har veiskiller, der gitte spørsmål eller undersøkelser vil peke hvilken vei du skal gå i retning riktig tiltak. Det er nyttig å ha tenkt gjennom dette. For eksempel: Hvilke opplysninger og undersøkelser trenger du for å bestemme deg for at en luftveisinfeksjon er bakteriell og dermed skal behandles med antibiotika? Eller: Hvilke opplysninger og undersøkelser trenger du for å bestemme deg for om en besvimelse er kardial eller vasovagal?

\section{Tillit og trygghet}

Som legevaktlege har du ett møte med pasienten. Det betyr at du må skape tillit på kort tid.

La pasienten fortelle sin historie uten at du avbryter. Merk deg underveis hva du vil spørre utdypende om, men vent til historien er ferdig fortalt. Dermed opplever pasienten at du har lyttet, og de fleste finner dette svært tillitvekkende. Historien blir også mer informativ når pasienten får fortelle den uten at den oppstykkes og redigeres av dine spørsmål (2). De færreste snakker lenger enn to minutter, og samlet sett sparer du mye tid på denne måten (3).

Gjør deretter en målrettet klinisk undersøkelse. Legekunsten krever visse kliniske grunntrinn, uavhengig av diagnostisk verdi, som å inspisere en vond hals og auskultere den som hoster. Pasientene forventer å bli undersøkt, og den kliniske undersøkelsen skaper tillit. Undervurder aldri betydningen av å ta på pasienten. Å ta på er å røre ved.

Når du har lyttet til og undersøkt, har du satt deg i en posisjon der det er større mulighet for at pasienten vil ha tillit til deg og akseptere din vurdering og det tiltaket du setter i verk. Dette vil også styrke placeboeffekten. Det er ikke umulig at en pasient som stoler på legen, blir fortere frisk. Det er ganske sikkert at en pasient som stoler på legen, har det bedre under forløpet (4).

Alle beslutninger legevaktleger treffer, er beheftet med usikkerhet. Dette er en 
usikkerhet vi som leger bærer for pasientene. Ikke undergrav tilliten med alle mulige slags forbehold, men informer om hva du forventer vil skje videre og om hva pasienten skal gjøre om utviklingen ikke blir som forventet.

Undervurder aldri hvor redd pasienten er for at det er noe farlig. Dette gjelder også ved tilstander du selv oppfatter som helt bagatellmessige. Om du kan stå inne for å si at noe ikke er farlig, så si dette på et tidlig tidspunkt når du informerer om din vurdering og videre tiltak. En mindre engstelig pasient vil bedre kunne få med seg den øvrige informasjonen du vil gi.

\section{Arbeidsform}

Det meste av arbeidet vil bli utført sittende på legekontoret, der pasientene håndteres en og en. Det vil variere mellom legevakter hva slags diagnostisk utstyr og behandlingsmuligheter som er tilgjengelig. Det vil også variere hva slags oppgaver hjelpepersonell kan utføre og hva du må gjøre selv.

Du må kunne håndtere mange pasienter samtidig. Du må regne med å bli avbrutt i ditt arbeid for å gjøre tilsyn av pasienter triagert med høy hastegrad. Ett poeng med dette tidlige tilsynet er å fange opp dem som krever rask innleggelse. Et annet poeng er rask start av behandling eller smertelindring der det trengs. Et tredje poeng er å målrette de undersøkelsene du vil ha for å avklare situasjonen. Dette tidlige tilsynet kan ofte gjøres svært kort - tre spørsmål og en hånd på pasienten kan være nok til å finne ut hva som må gjøres videre. Vend så tilbake til pasienten når svar på undersøkelser foreligger eller når effekten av initialbehandlingen kan evalueres. I mellomtiden fortsetter du med dine øvrige pasienter.

Journalnotatet skal være så kort som mulig og så omfattende som nødvendig. Det er særlig viktig å sette frem vurdering og tiltak i klartekst. Du skal tydelig vise frem beslutningen som er fattet, slik at neste lege lett kan se hva du har vurdert og gjort.
Det kan mange ganger være gunstig at pasientene får med seg utskrift av dagens notat når de går. Da kan vurderings-/tiltaksdelen av journalnotatet brukes til å informere pasientene også skriftlig om hva de

\section{«Undervurder aldri betydningen av å ta på pasienten. A ta på er à røre ved»}

skal gjøre og være oppmerksomme på. Om det finnes mulighet til å sende dagens notat elektronisk til pasientens fastlege, er dette svært nyttig.

\section{Innleggelse og konferering med sykehus}

Bestem deg før du tar en telefon om du ringer for å legge inn pasienten eller om du ringer for å spørre sykehuslegen til råds. Det er også klokt å fortelle sykehuslegen hvorfor du ringer relativt raskt etter at du har presentert deg.

Til syvende og sist er det du som bestemmer om pasienten skal tilses ved sykehus eller ikke. Det er slett ikke sikkert at sykehuslegen vet mer om grenseoppgangene mellom legevakt og sykehus enn du gjør.

\section{Fotarbeid for legevaktleger \\ Som legevaktlege skal du være god på det enkle}

Det vil si at du må beherske de vanlige og de farlige tilstandene som ses på legevakt, være våken overfor kliniske bilder som ikke passer med de vanlige, ta mål av deg til å bli en god kliniker, møte pasientene med høflighet og interesse og snakke med dem slik at de forstår hva de skal gjøre og hva du tenker å gjøre med dem.
Som legevaktlege skal du være enkel med det kompliserte

Det betyr at du skal møte det uoversiktlige, vanskelige og forvirrende på en systematisk måte og aldri miste av syne at du skal fatte en beslutning om et tiltak.

Denne teksten er basert på et skriv utarbeidet ved Allmennlegevakten ved Legevakten i Oslo til bruk i opplæringen av nyansatte leger. Utarbeidingen av skrivet var inspirert av daværende seksjonsoverlege Harald Vallgårda, som mente at vi måtte vise våre nye kolleger at legevakt er noe eget som vi kan, en ferdighet de kan tilegne seg, noe de kan bli gode på. Skrivet har vært i bruk siden 2011 og ble utviklet og siden revidert i dialog med ledelsen og legeskiftlederne ved Allmennlegevakten. Særlig har Anne Kathrine Nore hatt innspill av stor betydning.

\section{Odd Martin Vallersnes}

o.m.vallersnes@medisin.uio.no

Odd Martin Vallersnes (f. 1969) er spesialist i allmennmedisin og legeskiftleder ved Allmennlegevakten ved Legevakten i Oslo, der han har arbeidet siden 1998. Han er også ph.d.-stipendiat ved Avdeling for allmennmedisin ved Universitetet i Oslo.

Forfatter har fylt ut ICMJE-skjemaet og oppgir ingen interessekonflikter.

\section{Litteratur}

1. Hunskår S, Blinkenberg J, Bondevik GT et al. Nasjonale krav til legevakt og fremtidens øyeblikkelig hjelp-tilbud i kommunene. Oppdrag fra Akuttutvalget. Rapport nr. 7-2014. Bergen: Nasjonalt kompetansesenter for legevaktmedisin, Uni Research Helse, 2014

2. Schei E. Lytt. Legerolle og kommunikasjon. Bergen: Fagbokforlaget, 2015.

3. Marvel MK, Epstein RM, Flowers K et al. Soliciting the patient's agenda: have we improved? JAMA 1999; 281: 283-7.

4. Finniss DG, Kaptchuk TJ, Miller F et al. Biological, clinical, and ethical advances of placebo effects. Lancet 2010; 375: 686-95.

Mottatt 23.2. 2016, første revisjon innsendt 11.7.2016, godkjent 7.11. 2016. Redaktør: Martine Rostadmo. 